\title{
Why do some conduits get infected and others don't?
}

\author{
Carlos M. Mery, MD, MPH, and Charles D. Fraser, Jr, MD
}

\author{
From the Division of Congenital Heart Surgery, Department of Surgery, Texas Children's Hospital/Baylor College \\ of Medicine, Houston, Tex. \\ Disclosures: Authors have nothing to disclose with regard to commercial support. \\ Received for publication Sept 8, 2017; accepted for publication Sept 13, 2017; available ahead of print Oct 7 , \\ 2017. \\ Address for reprints: Carlos M. Mery, MD, MPH, Congenital Heart Surgery, Texas Children's Hospital, 6621 Fan- \\ nin St, MC19345H, Houston, TX 77030 (E-mail: cmmery@texaschildrens.org). \\ J Thorac Cardiovasc Surg 2018;155:333-4 \\ $0022-5223 / \$ 36.00$ \\ Copyright (C) 2017 by The American Association for Thoracic Surgery \\ https://doi.org/10.1016/j.jtcvs.2017.09.052
}

Bovine jugular vein (BJV) grafts increasingly have been used for right ventricular outflow tract reconstruction. Stent-mounted BJV grafts now also are implanted widely as percutaneous valves in different positions.

Despite an initial enthusiasm with the use of BJV conduits, our group ${ }^{1}$ and others ${ }^{2-4}$ have reported a high risk of late endocarditis. In our series, ${ }^{1}$ which included 245 patients with BJV conduits, $6 \%$ of conduits developed endocarditis with a median follow-up of 7 years, and it was estimated that as many as $17 \%$ of patients would develop endocarditis 10 years after conduit placement. BJV grafts were associated with a 9-fold increased risk of endocarditis compared with homografts. Interestingly, the risk of endocarditis increased with time, and most of the cases happened after 7 years from implantation. Similar concerns have been raised for percutaneous BJV valves.

The mechanism behind the high incidence of endocarditis in BJV grafts is unclear. Some of the theories include increased susceptibility of these conduits to bacterial adherence, increased thrombogenicity, turbulent flow, and late tissue degeneration. ${ }^{1}$ In this issue of the Journal, Veloso and colleagues ${ }^{6}$ assessed the in vitro adherence of 3 bacterial strains (Staphylococcus aureus, Staphylococcus epidermidis, and Streptococcus sanguis) to small pieces of bovine pericardial patch, BJV, and cryopreserved homograft under both static and simulated shear stress conditions. In general, bacterial adherence was relatively similar for all tissues. The authors concluded that the surface composition of the conduits, bacterial surface proteins, and shear forces were not the most important determinants of the greater risk of endocarditis in BJV conduits.

The results of this study somewhat contradict a recent study by Jalal and colleagues, ${ }^{7}$ in which the authors found greater bacterial adherence in percutaneous BJV valves compared with homemade stents with bovine and porcine pericardium. Interestingly, bacterial adherence significantly increased in traumatized BJV valve leaflets. The main differences between these 2 studies include the use of actual strains isolated from patients with endocarditis in the study by Jalal and colleagues ${ }^{7}$ compared with commercial

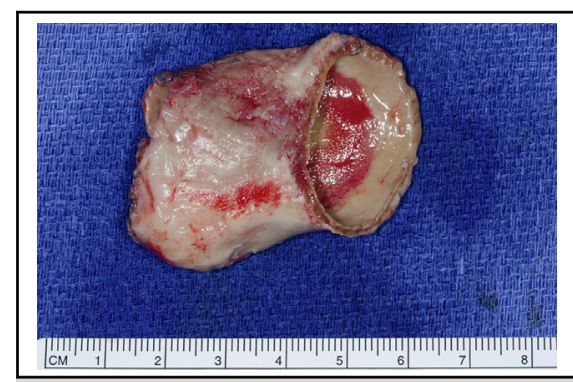

Necrotic and poorly incorporated explanted bovine jugular conduit.

\section{Central Message}

The mechanism for increased risk of endocarditis in bovine jugular grafts is poorly understood.

See Article page 325 .

bacterial isolates ${ }^{6}$ and the use of stented and traumatized valves by Jalal and colleagues ${ }^{7}$ instead of intact tissue.

Even though these studies represent an important step in trying to define the mechanism of endocarditis in BJV grafts, it is important to note that in vitro bacterial adherence to fresh tissue is likely significantly different than in vivo bacterial adherence and invasion over time. Most cases of endocarditis in BJV conduits occur years after implantation of the conduit. In our experience, BJV conduits seem to be poorly incorporated, and sometimes clearly necrotic, when explanted years after placement (Figure 1). It is thus feasible that poor incorporation of the conduit associated with worsening shear stress and thrombi from

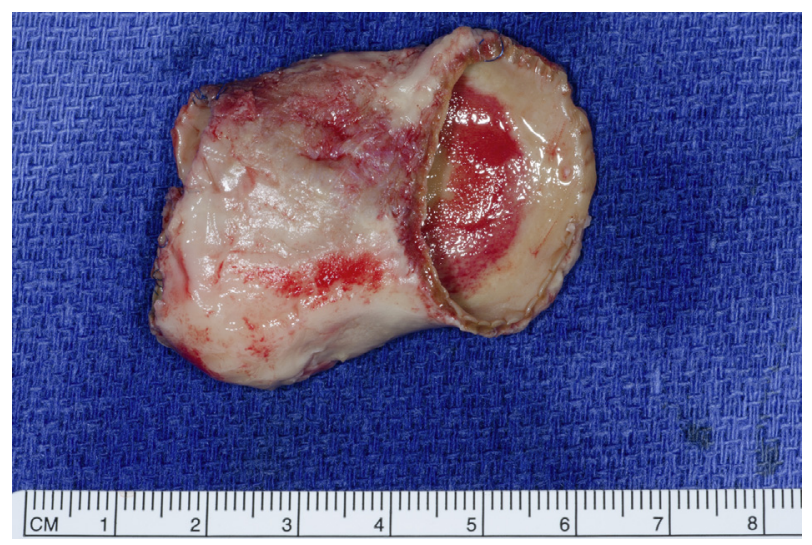

FIGURE 1. Necrotic and poorly incorporated bovine jugular conduit explanted 1 year after implantation due to branch pulmonary artery compression caused by a sterile pseudocyst around the conduit. 
degeneration of the conduit may prompt bacterial adherence and invasion of this necrotic tissue. These late conditions are obviously difficult to simulate in an in vitro setting. Nonetheless, we applaud these early efforts to define the mechanism of endocarditis and hope that further studies can get us closer to determine why some conduits get infected and others don't.

\section{References}

1. Mery CM, Guzmán-Pruneda FA, De León LE, Zhang W, Terwelp MD, Bocchini CE, et al. Risk factors for development of endocarditis and reintervention in patients undergoing right ventrile to pulmonary artery valved conduit placement. J Thorac Cardiovasc Surg. 2016;151:432-9.

2. Ugaki S, Rutledge J, Al Aklabi M, Ross DB, Adatia I, Rebeyka IM. An increased incidence of conduit endocarditis in patients receiving bovine jugular vein grafts compared to cryopreserved homograft for right ventricular outflow reconstruction. Ann Thorac Surg. 2015:99:140-6.

3. Malekzadeh-Milani S, Ladouceur M, Iserin L, Bonnet D, Boudjemline Y. Incidence and outcomes of right-sided endocarditis in patients with congenital heart disease after surgical or transcatheter pulmonary valve implantation. $J$ Thorac Cardiovasc Surg. 2014;148:2253-9.

4. Albanesi F, Sekarski N, Lambrou D, Von Segesser LK, Berdajs DA. Incidence and risk factors for Contegra graft infection following right ventricular outflow tract reconstruction: long-term results. Eur J Cardiothorac Surg. 2014;45:1070-4.

5. Hascoet S, Mauri L, Claude C, Fournier E, Lourtet J, Riou JY, et al. Infective endocarditis after percutaneous pulmonary valve implantation with the Melody and Sapien valves. JACC Cardiovasc Interv. 2017;10:510-7.

6. Veloso TR, Claes J, Van Kerckhoven S, Ditkowski B, Hurtado-Aguilar LG, Jockenhoevel S, et al. Bacterial adherence to graft tissues in static and flow conditions. J Thorac Cardiovasc Surg. 2018;155:325-32.e4.

7. Jalal Z, Galmiche L, Lebeaux D, Villemain O, Brugada G, Patel M, et al. Selective propensity of bovine jugular vein material to bacterial adhesions: an in-vitro study. Int J Cardiol. 2015;198:201-5. 